\title{
Treprostinil increases the number and angiogenic potential of endothelial progenitor cells in children with pulmonary hypertension
}

\author{
David M. Smadja $\cdot$ Laetitia Mauge $\cdot$ Pascale Gaussem • \\ Clément d'Audigier · Dominique Israel-Biet • \\ David S. Celermajer · Damien Bonnet • Marilyne Lévy
}

Received: 10 September 2010/ Accepted: 19 October 2010/Published online: 4 November 2010

(C) The Author(s) 2010. This article is published with open access at Springerlink.com

\begin{abstract}
Background Pulmonary vasodilators in general and prostacyclin therapy in particular, have markedly improved the outcome of patients with pulmonary arterial hypertension (PAH). As endothelial dysfunction is a key feature of $\mathrm{PAH}$, and as endothelial progenitor cells (EPC) may contribute to vascular repair in PAH, we suspected that prostacyclin therapy might enhance EPC numbers and functions. In the present study, objectives were to determine whether EPC may contribute to vasodilator treatment efficacy in PAH.
\end{abstract}

D. M. Smadja $(\varangle)$ - L. Mauge · P. Gaussem - C. d'Audigier .

D. Israel-Biet - D. Bonnet - M. Lévy

Université Paris Descartes, Paris, France

e-mail: david.smadja@egp.aphp.fr

D. M. Smadja · L. Mauge - P. Gaussem - C. d'Audigier Inserm Unité 765, Faculté de Pharmacie, and AP-HP, Hôpital

Européen Georges Pompidou, Haematology Department,

20 rue leblanc, 75015 Paris, France

D. Israel-Biet

AP-HP, Hôpital Européen Georges Pompidou, Pneumology

Department, Paris, France

D. M. Smadja

Vascular Biology Program, Children's Hospital,

Harvard Medical School, Boston, MA, USA

D. Israel-Biet · M. Lévy

UPRES EA4068, UFR Biomédicale des Saints Pères,

Paris, France

D. S. Celermajer

Sydney Medical School, University of Sydney, Sydney,

NSW 2006, Australia

D. Bonnet · M. Lévy

AP-HP, Hôpital Necker-Enfants Malades, Paris, France
Methods We quantified CD34+ cells, CFU-Hill and ECFC (endothelial colony forming cells) in peripheral blood from children with idiopathic PAH $(n=27)$ or PAH secondary to congenital heart disease $(n=52)$. CD34+ were enumerated by flow cytometry, CFU-Hill and ECFC by a culture assay. ECFC grown ex vivo were tested for their angiogenic capacities before and after prostacyclin analog therapy (subcutaneous treprostinil).

Results ECFC counts were significantly enhanced in the 8 children treated with treprostinil, while no change was observed in children receiving oral therapy with endothelin antagonists and/or PDE5 inhibitors. CD34+ cell and CFUHill counts were unaffected. ECFC from patients treated with treprostinil had a hyperproliferative phenotype and showed enhanced angiogenic potential in a nude mouse preclinical model of limb ischemia.

Conclusions ECFC may partly mediate the clinical benefits of prostanoids in pulmonary arterial hypertension.

Keywords Pulmonary hypertension - Congenital heart disease - Vasodilator treatment - Treprostinil · EPC

\section{Introduction}

Pulmonary vascular disease (PVD) can cause pulmonary arterial hypertension (PAH), usually leading to right heart failure and death if left untreated [1]. Endothelial cell dysfunction is a hallmark of both idiopathic PAH and PAH secondary to congenital heart disease [2-4].

A role of endothelial progenitor cells (EPC) in vascular repair and new vessel formation has been described [5-7]. EPC mobilized from bone marrow and/or resident locally in the lung, are thought to be important in maintaining vascular homeostasis; and there is a growing interest in the 
potential therapeutic or diagnostic use of EPC during PAH. Experimental and clinical studies have examined the possible contribution of EPC to the pathogenesis of PAH, but reported EPC counts in patients with pulmonary hypertension have been inconsistent [8-11]. Several types of EPC are defined, depending on the method used (flow cytometry or culture) and their characteristics. At least two populations of EPC have been described [5, 12]. "Early" EPC are spindle-shaped and express both endothelial and leukocyte markers. Quantification of this cell population, as described by Hill, utilizes a commercial kit that identifies so-called "CFU-Hill" [13]. The number of CFU-Hill in peripheral blood has been reported to correlate inversely with cardiovascular risk factors [13]. "Late" EPC, also called endothelial colony-forming cells (ECFC) [7, 14], develop after 1-3 weeks of culture and have the characteristics of precursor cells committed to the endothelial lineage. Both EPC subtypes have therapeutic potential but in vivo, cells that merge into neovessels have an ECFC phenotype [6, 7].

EPC transplantation was recently shown to improve pulmonary hypertension in a rat model $[15,16]$, while Wang et al. [17] found that EPC transplantation improved exercise capacity and pulmonary hemodynamics in patients with idiopathic PAH, and a contemporary open-label, nonrandomized pilot trial showed that EPC transplantation led to significant improvements in exercise capacity, New York Heart Association functional class, and pulmonary hemodynamics in children with idiopathic PAH [18].

"Pulmonary vasodilator" therapy has greatly improved the prognosis of patients with PAH $[19,20]$. In particular, parenteral prostacyclin improves the outcome of patients with PVD, not only by inducing pulmonary vasodilation but also by altering pulmonary vascular structure and function during long-term administration. Intravenous prostacyclin is currently recommended for patients of all ages with WHO functional class IV disease, and as add-on therapy for patients remaining in class III despite correctly dosed treatment with endothelin-receptor antagonists (ERA) and phosphodiesterase-5 inhibitors (PDE5) [19, 20]. Subcutaneous treprostinil, a parenteral prostanoid, is sometimes preferred to an intravenous prostacyclin in children, especially to avoid the long-term risks associated with chronic intravenous therapy.

Given the possible relationship between EPC and treatment efficacy, we therefore examined the impact of treprostinil therapy on the number and functional capacity of EPC in children with advanced PAH.

\section{Patients and methods}

\section{Study population (Table 1)}

This prospectively designed study was aimed at determining the numbers and functional capacities of EPC before and after vasodilator treatment, and especially after treprostinil therapy. Blood samples were collected during outpatient visits from patients already on single- or dualagent therapy. In the 8 treprostinil-treated patients, EPC were studied before treatment initiation, 2 and 5 days later and monthly thereafter.

The study was approved by the institutional ethics committee of Necker-Enfants Malades hospital, and the parents gave their signed informed consent. Fifty-two consecutive patients with CHD and PAH, and 27 consecutive patients with idiopathic PAH (Table 1) were enrolled between February 2008 and 2010. The 27 patients with idiopathic PAH had a median age of 6 years. Among the patients with CHD, 28 (median age 2 years) had reversible $\mathrm{PAH}$, as defined by normal pulmonary pressure 6 months after surgery, while 24 (median age 8 years) had irreversible PAH, based on persistently elevated pulmonary artery pressure and pulmonary vascular resistance. Children with irreversible PAH were older than children with reversible and idiopathic $\mathrm{PAH}$ ( $P=0.01$ and $P=0.06$, respectively) and had lower oxygen saturation values $(P=0.02$ and $P=0.0008$, respectively). Pulmonary artery pressure was similar in the three groups (Table 1). Patients with familial PAH associated with BMPR2 mutations were not included in this study, because of a possible impact of BMP on EPC angiogenic properties [6, 21,22].

Table 1 Characteristics of the patients

\begin{tabular}{lllclll}
\hline & $\begin{array}{l}\text { Reversible } \\
\text { PAH } \\
(n=28)\end{array}$ & $\begin{array}{l}\text { Irreversible } \\
\text { PAH } \\
(n=22)\end{array}$ & $\begin{array}{l}\text { Idiopathic PAH } \\
(n=27)\end{array}$ & $\begin{array}{l}P \text { value reversible } \\
\text { versus irreversible } \\
\text { PAH }\end{array}$ & $\begin{array}{l}P \text { value reversible } \\
\text { versus } \\
\text { Idiopathic PAH }\end{array}$ & $\begin{array}{l}P \text { value irreversible } \\
\text { versus } \\
\text { Idiopathic PAH }\end{array}$ \\
\hline Age (y) & $2(2.7-6.5)$ & $8(6.1-16.4)$ & $6(4.5-8.4)$ & $0.01^{*}$ & 0.16 & 0.06 \\
Saturation (\%) & $96(89.2-95.3)$ & $86(79.8-91.3)$ & $97.5(93.5-98.4)$ & $0.02^{*}$ & 0.07 & $0.0008^{*}$ \\
Mean PAP & $55(50-66.2)$ & $60(50.3-66.5)$ & $53(46-56.5)$ & 0.13 & 0.15 & 0.95 \\
\hline
\end{tabular}

Data are expressed as medians and confidence intervals (95\%CI). Baseline characteristics were compared with Wilcoxon's rank sum test for non normally distributed variables (age) and Student's unpaired test otherwise

$* P<0.05$, reversible versus irreversible PAH 
Indeed, BMPR2 mutations have been reported to affect both early [23] and late EPC, the latter showing a hyperproliferative phenotype and an impaired capacity to form vascular networks [22]. Because of adverse effects reported with IV epoprostenol and inhaled prostanoids, subcutaneous treprostinil was used as first-line add-on therapy for 8 young children who deteriorated while receiving combined oral therapy with an endothelin receptor agonist and a PDE5 inhibitor. Three of them had idiopathic PAH and five patients had PAH associated with a congenital heart defect. The decision to add subcutaneous tresprostinil was based on their clinical status (change in functional class), including right ventricular dysfunction (hepatomegaly, increase in tricuspid regurgitation volume, dilation of hepatic veins and the inferior vena cava) in seven patients. Two of them also had syncope. One patient in functional class II had severe complications associated with the central venous line used to deliver epoprostenol. All the patients had right heart catheterization prior to treprostinil treatment. Treprostinil administration was initiated at hospital, through a subcutaneous catheter in the outer leg. All the patients initially received a fixed dose of $1.25 \mathrm{ng} / \mathrm{kg} / \mathrm{min}$. The dose was then daily increased by $1.25 \mathrm{ng} / \mathrm{kg} / \mathrm{min}$, reaching an average of $20 \mathrm{ng} / \mathrm{kg} / \mathrm{min}$ at hospital discharge. During treprostinil treatment, site pain was evaluated every $6 \mathrm{~h}$ using standard pain scales adapted to age. After hospital discharge the treprostinil dose was adjusted at monthly out-patient visits and reached an average of $40 \mathrm{ng} / \mathrm{kg} / \mathrm{min}$. Technical assistance was provided at home by specialized nurses trained in the management of parenteral prostanoid therapy in $\mathrm{PAH}$ patients. All patients had experienced a clinical improvement performed, for oldest children by 6MWT, and they all showed an improvement in oxygen saturation and functional status, as they were all in functional class I or II. In five patients who had right heart catheterization after treprostinil, pulmonary arterial pressure did not change but cardiac output increased and pulmonary vascular resistance decreased.

Flow cytometric quantification of CD34+ hematopoietic progenitor cells (HPC)

Circulating CD34+ cells were counted by flow cytometry (FC500 Cytometer; Beckman Coulter, Villepinte, France) after staining of whole blood with a fluorescein isothiocyanate (FITC)-labeled monoclonal mouse antihuman CD45 antibody, a phycoerythrin (PE)-labeled monoclonal mouse antihumanCD34 antibody, and 7AAD (Stemkit ${ }^{\circledR}$; Beckman Coulter). Absolute numbers of CD34+ cells $\mu \mathrm{l}^{-1}$ were determined by using calibration beads, as recommended by the manufacturer.

EPC quantification by cell culture

Blood was diluted 1:1 with PBS, 0.2 M EDTA and overlaid on Histopaque-1077 (Sigma-Aldrich, Saint-Quentin
Fallavier, France). Cells were centrifuged at $100 \mathrm{~g}$ for $20 \mathrm{~min}$. Mononuclear cells (MNC) were collected and washed 3 times in PBS, 0.2 M EDTA. CFU-Hill were cultured with the EndoCult ${ }^{\circledR}$ Liquid Medium kit (StemCell Technologies, Vancouver, BC, Canada) according to the manufacturer's instructions. Briefly, MNC were resuspended in complete EndoCult ${ }^{\circledR}$ medium and seeded at $5 \times 10^{6}$ cells/well in fibronectin-coated tissue culture plates (BD, Becton-Dickinson Biosciences). After $48 \mathrm{~h}$, to obtain CFU-Hill, nonadherent cells were collected and plated in Endocult ${ }^{\circledR}$ buffer at $10^{6}$ cells/well in 24-well fibronectin-coated plates. CFU-Hill colonies were counted after another 3 days, as recommended by the manufacturer. As previously described [7, 13, 24], these cells did not replicate in vitro and gradually disappeared 20 days after plating (Fig. 1b). To obtain ECFC, adherent cells at $48 \mathrm{~h}$ were kept in 6-well fibronectin-coated plates in EGM2 medium (Lonza, Saint-Beauzire, France) composed of endothelial cell basal medium-2 (EBM2), 5\% fetal bovine serum (FBS) and growth factors. ECFC appeared between 7 and 30 days of culture and consisted of well-circumscribed cobblestone monolayers (Fig. 1d). Colonies were counted with an inverted microscope at $\times 20$ magnification. The colonies were then harvested, trypsinized and reseeded in 6-well plates for complementary studies.

\section{ECFC proliferation assay}

After $16 \mathrm{~h}$ of serum and growth-factor privation, ECFC were incubated for $48 \mathrm{~h}$ in EBM medium, 5\% FBS. Proliferation was examined after $48 \mathrm{~h}$ by measuring cell phosphatase activity based on the release of paranitrophenol (pNPP) (Sigma) measured at OD $405 \mathrm{~nm}$ (Fluostar optima; BMG labtech, Champigny-sur-Marne, France). Control cells were ECFC from cord blood [6, 25-27].

In vitro matrigel tube formation assay

After $16 \mathrm{~h}$ of serum and growth-factor privation, ECFC $\left(3 \times 10^{4}\right.$ cells/well) were seeded on growth factor-reduced Matrigel $(200 \mu \mathrm{l})(\mathrm{BD}$ Biosciences) in EBM2 medium and cultured for $18 \mathrm{~h}$ at $37^{\circ} \mathrm{C}$ with $5 \% \mathrm{CO}_{2}$. Capillary-like structures were observed by phase-contrast microscopy and networks formed by ECFC were quantified with Videomet software version 5.4.0.

Wound healing assay

A reproducible circular "wound" was made with a tip in confluent monolayers of ECFC cultured in 12-well plates. The surface area of the wound was measured at $\times 20$ magnification under an inverted microscope, then the medium was removed and the cells were further incubated for 4 or $18 \mathrm{~h}$ with EBM, 5\% FBS and VEGF $50 \mathrm{ng} / \mathrm{ml}$. Wound repair 

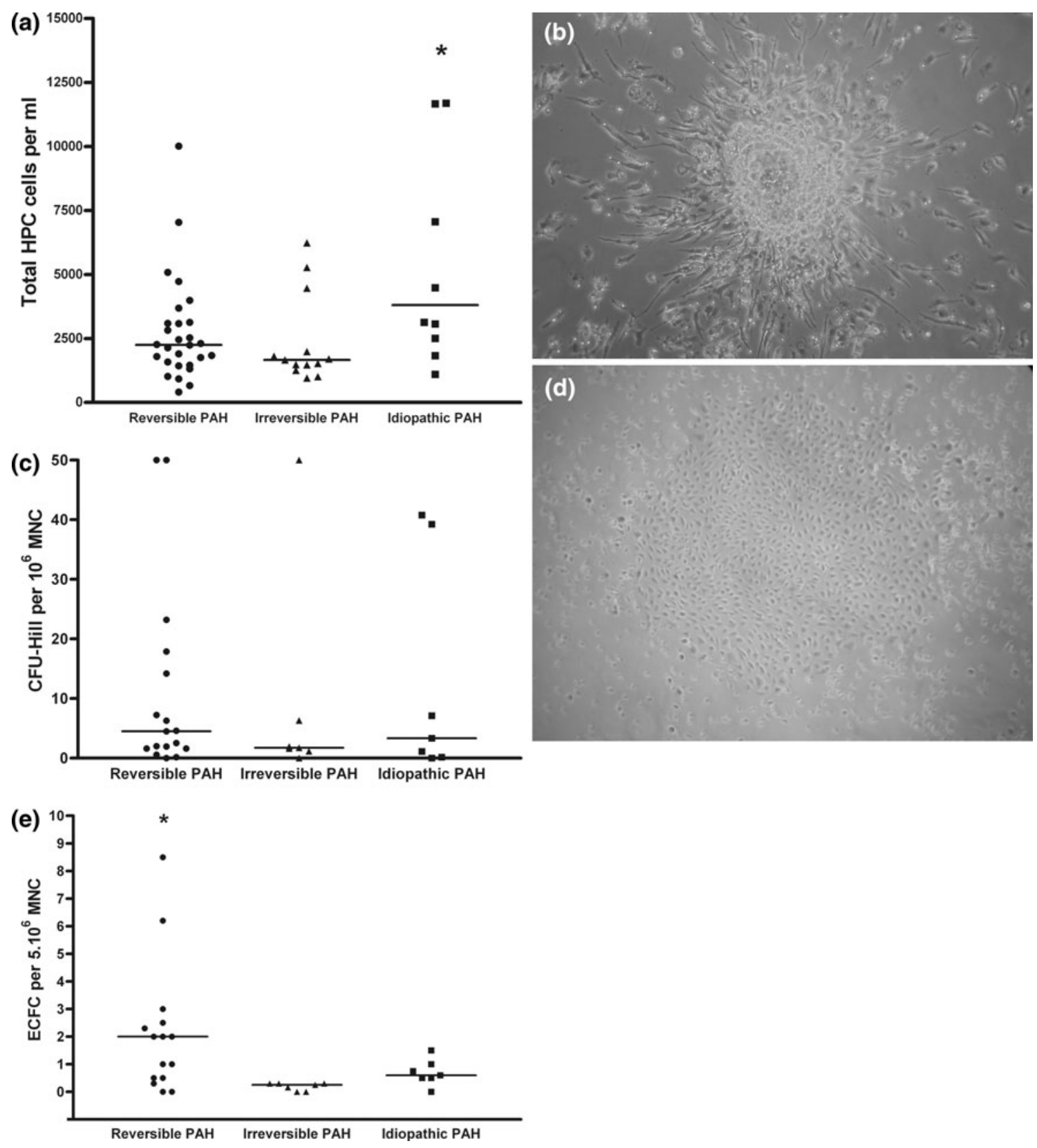

Fig. 1 Basal HPC, CFU-Hill and ECFC counts in the children with PAH. a NUMBER of CD34+ hematopoietic progenitor cells (HPC) determined by FACS analysis. HPC is significantly higher in idiopathic PAH group. b Representative phase-contrast photomicrograph of CFU-Hill colony obtained with Endocult ${ }^{\circledR}$. Note the central core of rounded cells with spindle-shaped cells sprouting through the

activity was calculated by expressing the area of the wound after 4 or $18 \mathrm{~h}$ of incubation as a percentage of the initial area.

ECFC angiogenic potential in a mouse model of hind-limb ischemia

Nude mice underwent surgery to induce unilateral hindlimb ischemia as described elsewhere $[6,28]$ and were

periphery. c Number of CFU-Hill counted with cell culture Endocult ${ }^{\circledR}$ assay. No difference was observed between the different patient groups. d Representative phase-contrast photomicrograph of an ECFC colony (mag. $\times 20$ ). e Number of ECFC by cell culture. ECFC is significantly higher in the reversible $\mathrm{PAH}$ group

randomized to receive an intravenous injection of $1 \times 10^{5}$ ECFC derived from the two treated patient groups or $1 \times 10^{5}$ ECFC derived from cord blood. Two independent groups of 20 mice were realized with, in each experiment, 5 mice injected with PBS, 5 mice with cord blood ECFC, 5 mice with ECFC from patients with oral therapy and 5 mice with ECFC from patients with SCtreprostinil. After 2 weeks, the ischemic/normal limb 
blood flow ratio was determined with a laser Doppler perfusion imaging system.

Statistical analysis

Baseline characteristics were compared between the groups by using Wilcoxon's rank sum test for non normally distributed variables and Student's unpaired test otherwise. Student's paired t test was used to compare progenitor cells from the same subjects before and after vasodilator treatment. Independent-samples tests were used to compare late EPC functional capacity in vitro and in mice. StatView or SAS statistical software (Cary, NC 27513, USA) was used for all statistical analyses, and 2-tailed $P$ values below 0.05 were considered to denote significant differences.

\section{Results}

HPC, CFU-Hill and ECFC counts before treatment

We found no difference in HPC counts between patients with reversible and irreversible $\mathrm{PAH}$ secondary to $\mathrm{CHD}$
[29], while HPC counts were significantly higher in patients with idiopathic PAH (Fig. 1a) $(P=0.02$ vs. patients with reversible $\mathrm{PAH}$ and 0.01 vs. patients with irreversible $\mathrm{PAH}$ ) in agreement with the data published by Diller et al. [10]. CFU-Hill counts after 5 days of culture did not differ across the three patient groups (Fig. 1c). By contrast, ECFC counts were significantly higher in reversible $\mathrm{PAH}$ than in irreversible and idiopathic $\mathrm{PAH}$ (Fig. 1e).

ECFC numbers are increased by prostanoid treatment

No significant change in HPC, CFU-Hill and ECFC were observed when all treated patients versus non treated patients were compared (Fig. 2a, b, c respectively, with $P=0.80,0.89$ and 0.15 ). Oral treatment (monotherapy or bitherapy) did not modify HPC, CFU-Hill and ECFC counts count (respectively, $P=0.52,0.64$ and 0.22 , Fig. 3). No change in HPC or CFU-Hill counts $(P=0.76$ and $P=0.19$, respectively, Fig. 3a, b) were observed after prostanoid therapy (SC treprostinil), while in contrast, this led to a significant increase in ECFC counts $(P=0.04$, Fig. 3c).
Fig. 2 HPC, CFU-Hill and ECFC counts in peripheral venous blood of patients with pulmonary hypertension, with and without treatment. a Number of CD34+ hematopoietic progenitor cells (HPC) determined by FACS analysis according to patient group. No difference is observed between the treated and non treated patients $(P=0.80)$. b Number of CFUHill colonies determined by cell culture according to patient group. No difference is observed between the treated and non treated patients $(P=0.89)$. c Number of ECFC determined by cell culture according to patient group. No difference is observed between the treated and non treated patients $(P=0.15)$
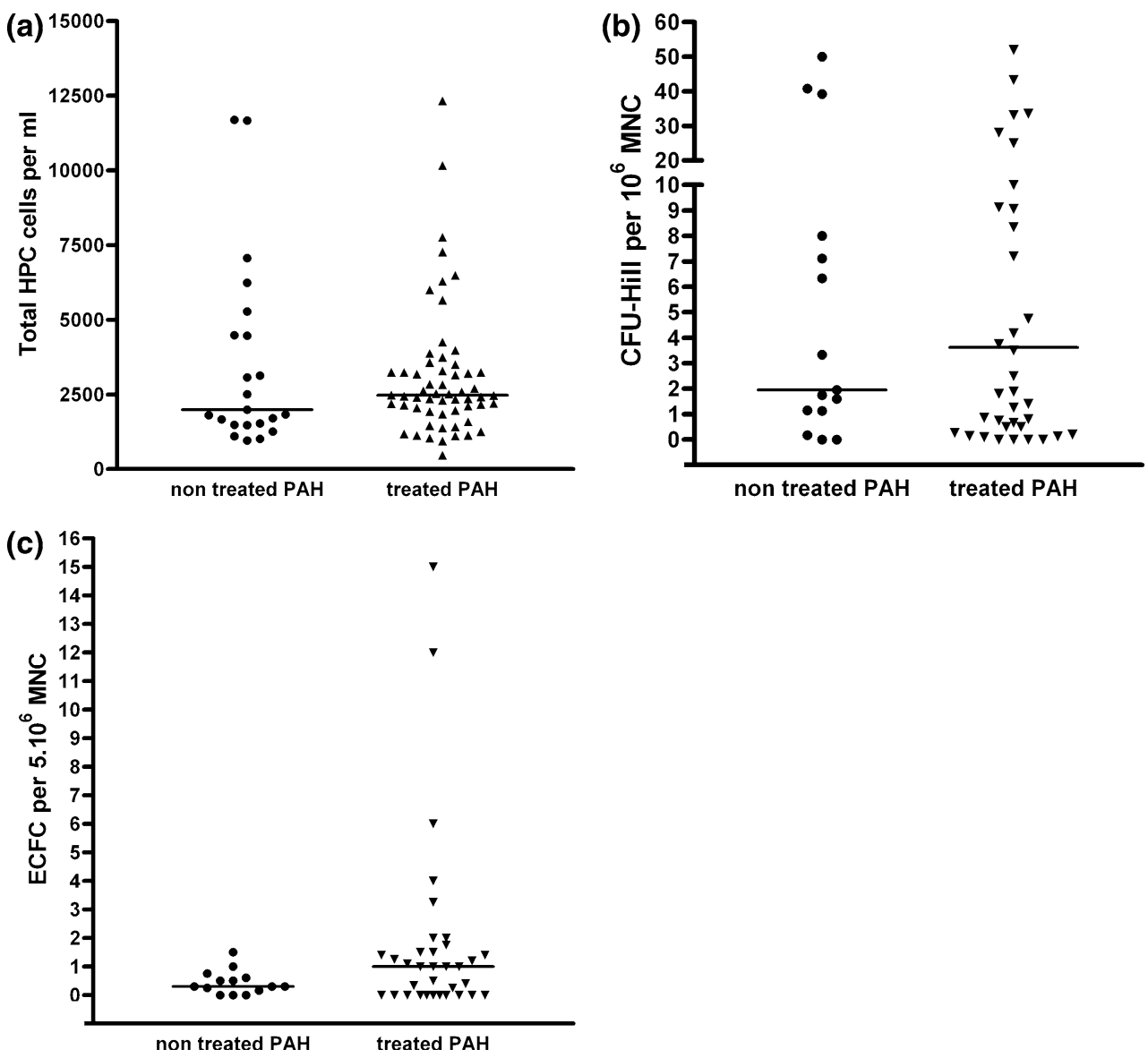

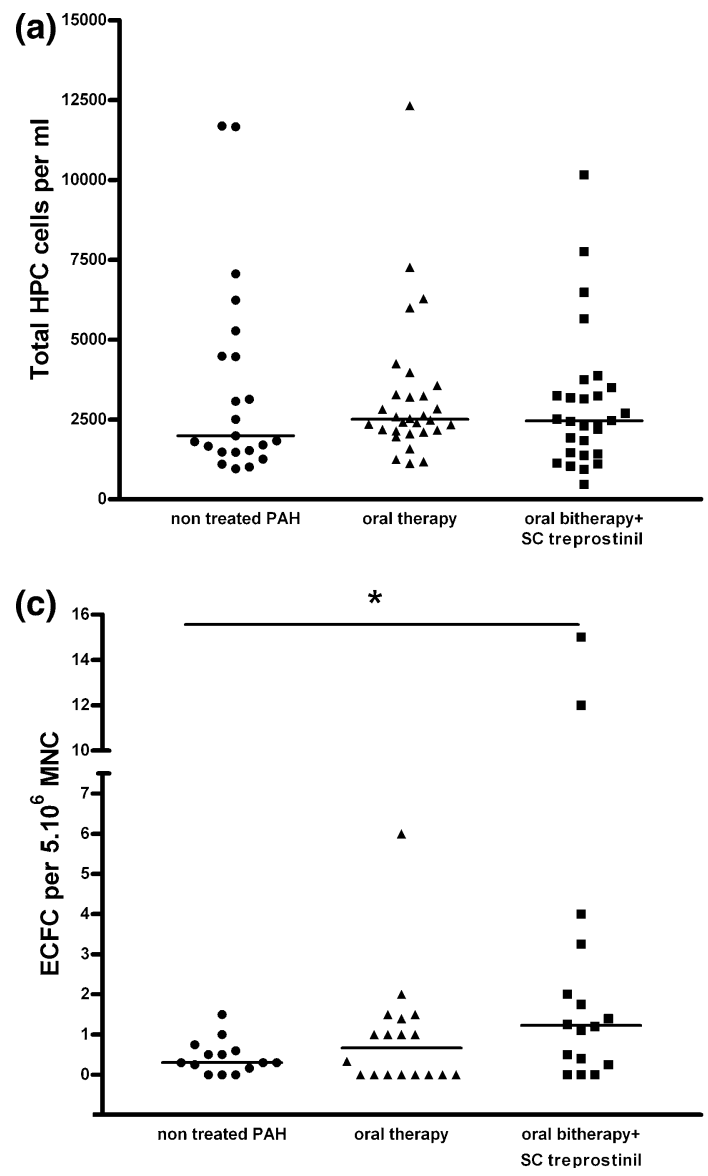

Fig. 3 HPC, CFU-Hill and ECFC counts in peripheral venous blood of patients with pulmonary hypertension according to treatment subtype. a No difference is observed in HPC according to treatment subtype (oral mono and/or bitherapy with or without subcutaneous treprostinil with respectively, a $P=0.52$ and 0.76 vs. not treated $\mathrm{PAH})$. b No difference is observed in CFU-Hill colonies determined

Treprostinil enhances the proangiogenic potential of ECFC

ECFC from patients receiving oral therapy, with or without SC treprostinil, were grown to confluence from single colonies. They retained the characteristic cobblestone aspect through numerous passages and stained positive for typical endothelial markers CD34, CD146, CD144, PAR-1 thrombin receptor and von Willebrand factor (data not shown). During the first 30 days of culture, cells cultured from patients receiving oral therapy plus SC treprostinil showed enhanced proliferation in EBM, 5\% FBS compared to cells from patients receiving only oral therapy (Fig. 4a). In vitro vascular network formation in Matrigel was similar with ECFC from patients treated with or without treprostinil (Fig. 4b, c), as was VEGF-induced migration in the wound healing assay (Fig. 4d, e).

In the preclinical model of hindlimb ischemia, $1 \times 10^{5}$ ECFC from each treatment group were injected

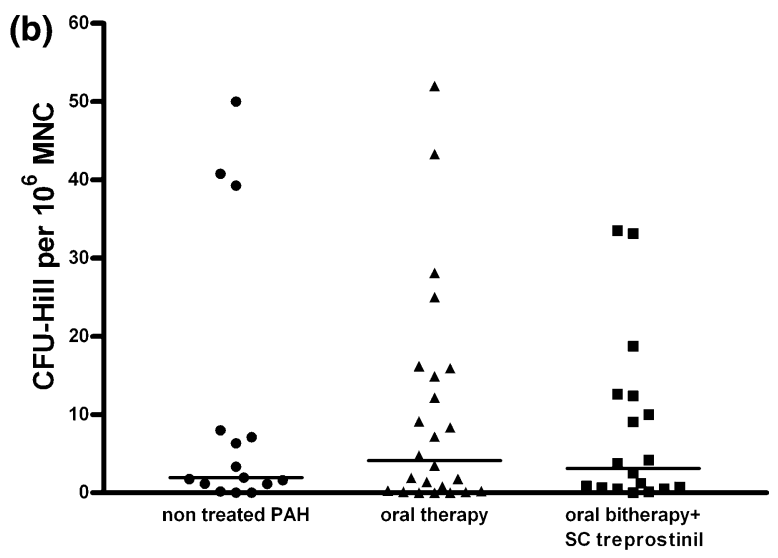

by cell culture according to treatment subtype (oral mono and/or bitherapy with or without subcutaneous treprostinil with respectively, a $P=0.64$ and 0.19 vs. not treated PAH). c No difference is observed in ECFC determined by cell culture after oral mono and/or bitherapy $(P=0.22)$ while a significant increase in ECFC was observed with subcutaneous treprostinil treatment $(* P=0.04)$

Fig. 4 Angiogenic potential of ECFC isolated from patients with pulmonary hypertension receiving vasodilator treatment. Each patientderived ECFC were individually analyzed for proliferation and angiogenic properties in vitro and in vivo. At least 4 different patients derived-ECFC were used in each case. a Cells from patients receiving oral therapy and SC treprostinil showed an increased proliferative potential (in EBM, 5\% FBS) compared with those from patients receiving oral therapy. Results are presented normalized to ECFC from cord blood (100\%). The mean and SEM of three experiments are shown $P<0.05$. b, $\mathbf{c}$ ECFC isolated from patients receiving oral therapy, with or without SC treprostinil, form intact vascular networks with similar efficiency. The mean and SEM of three experiments are shown. d, e VEGF-stimulated migration of ECFC in vitro in a wound healing assay was similar in patients receiving oral therapy with or without SC treprostinil. The mean and SEM of three experiments are shown. $\mathbf{f}$, g ECFC from patients receiving oral therapy, with or without SC treprostinil, were injected intravenously into nude mice having undergone femoral artery ligature. Injection of ECFC from patients receiving oral therapy only improved foot perfusion on day 14 to the same extent as control ECFC isolated from cord blood. ECFC from patients receiving oral therapy plus SC treprostinil improved foot perfusion on day 14 by $25 \%$ more than ECFC from patients receiving oral therapy alone $(P=0.012)$ and ECFC isolated from cord blood $(P=0.019)$ 

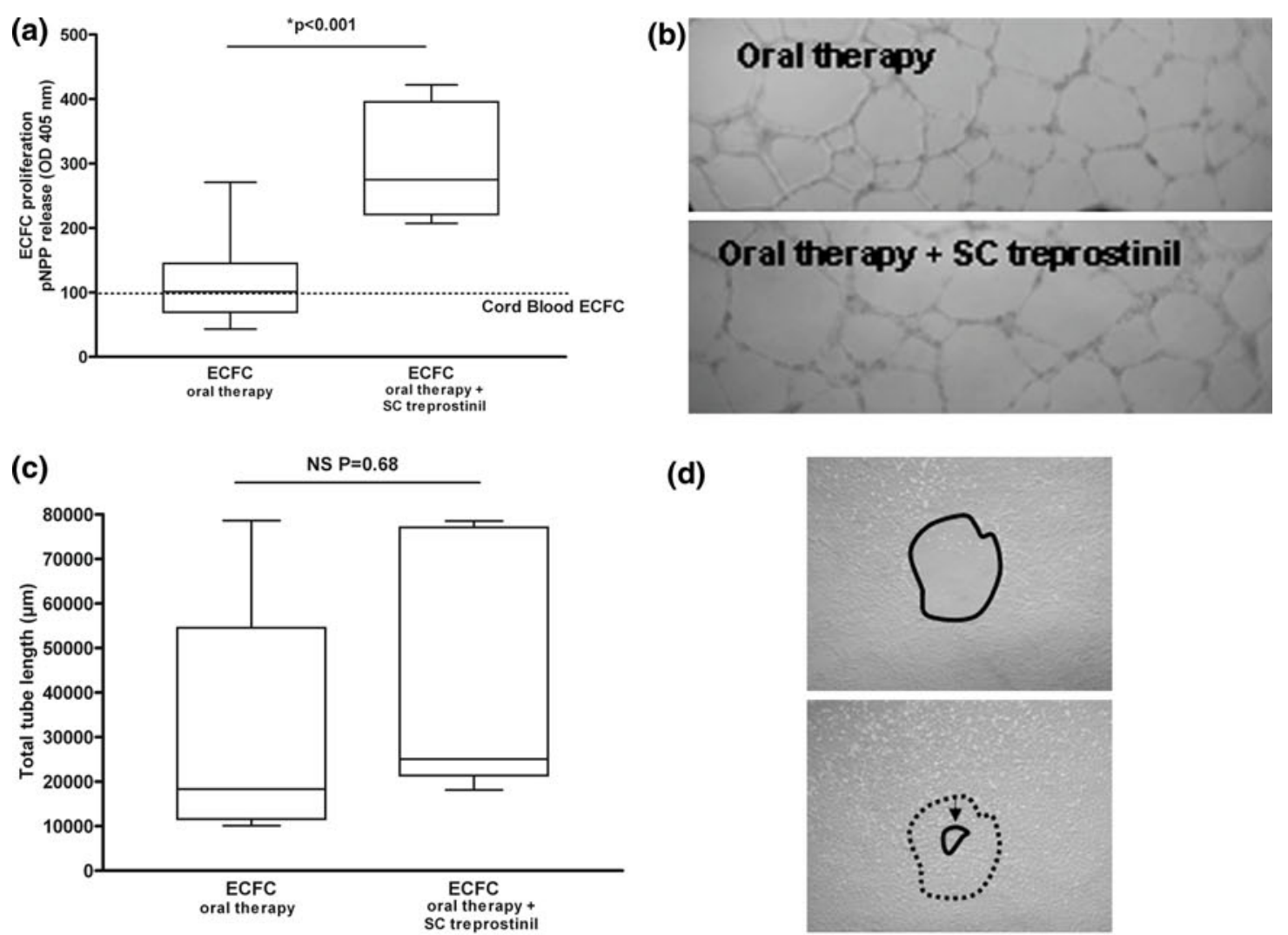

(f)
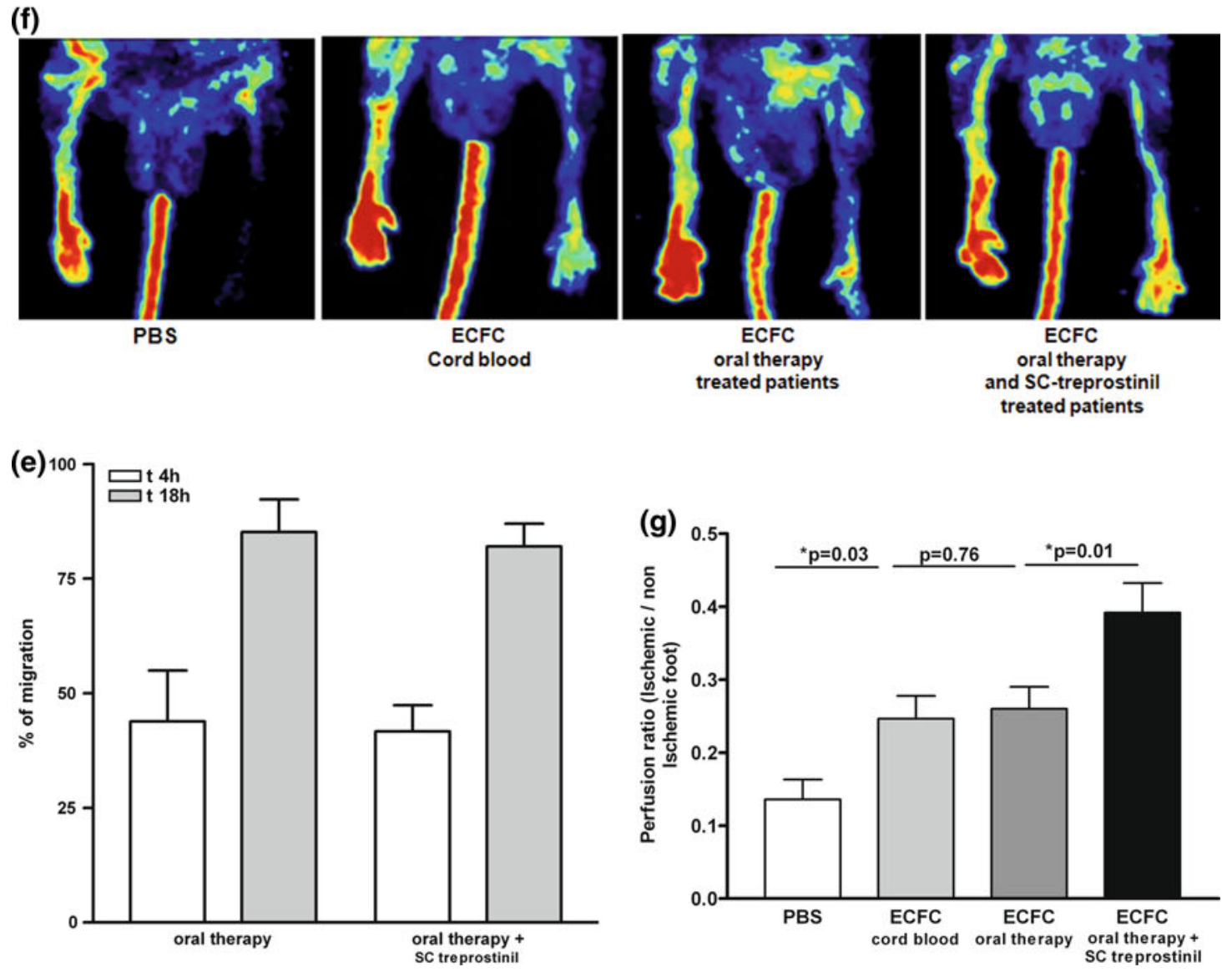

(d)
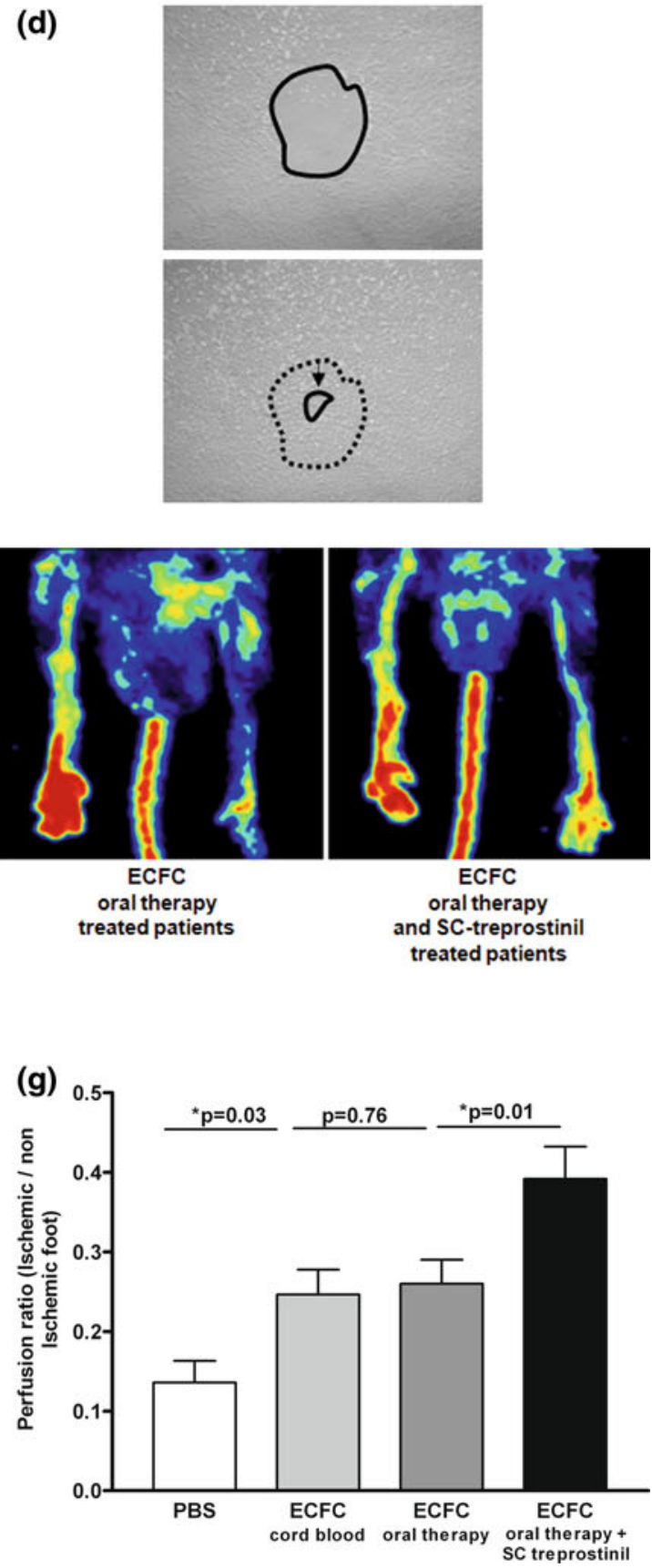
intravenously into nude mice with femoral artery ligature. Injection of ECFC from patients on oral therapy or from cord blood improved foot perfusion to a similar extent on day 14, while ECFC from treprostinil-treated patients improved foot perfusion on day 14 compared to ECFC from patients on oral therapy without SC treprostinil $(P=0.012)$ and ECFC from cord blood $(P=0.019$, Fig. 4f, g).

\section{Discussion}

Subcutaneous treprostinil markedly enhanced the number and functional capacity of ECFC isolated from children with severe PAH. As these cells are involved in angiogenesis and endothelial repair, this finding provides important insights into the mechanism of action of prostacyclin therapy in this setting.

The endothelium plays a central role in pulmonary vascular regulation, and endothelial dysfunction is increasingly viewed as critical for disease initiation and progression [3, 30]. We suspected that pharmacological treatment efficacy could be due, at least in part, to the endothelial repair capacity of ECFC. Irreversible and idiopathic PAH are associated with vascular remodeling and with smooth muscle and endothelial cell proliferation. Plexiform lesions have a similar histological aspect in idiopathic and irreversible PAH. We recently observed neoangiogenesis in lung surgical biopsy samples from patients with irreversible $\mathrm{PAH}$ due to CHD. This was associated to a proliferative endothelial phenotype with resistance to apoptosis [4]. These findings are consistent with a compensatory adaptive response to increased pulmonary blood flow and arterial pressure [31,32], in which ECFC are likely to play an important role. Standard methods used to assess endothelial function in the pulmonary circulation are invasive and complex [33], but recently developed ex vivo evaluations of endothelial biology have the potential to provide important insights [34].

In the past 20 years, pulmonary "vasodilator" therapy has greatly improved the prognosis of patients with PAH [19, 20], it is now clear that these agents do more than simply dilate pulmonary arterioles. Indeed, such treatments have been found to enhance revascularization and/or EPC recruitment in preclinical studies [35-37] and more recently in patients with critical limb ischemia [38]. Although phosphodiesterase 5 (PDE5) inhibitors [39-41] and endothelin receptor antagonists (ERA) [42-44] improve hemodynamic parameters, they have not been shown to significantly reduce mortality of PAH patients, contrary to prostanoids.

This difference between prostanoid, PDE5 inhibitors and ERA therapy in terms of mortality could result, at least in part, from a prostanoid-induced enhancement of EPC numbers and functional capacity, leading to improved vascular repair and/or new vessel formation. Two clinical studies recently showed that transplantation of angiogenic cells improved exercise capacity and pulmonary hemodynamics in adults and children with idiopathic pulmonary hypertension [17, 18]. In patients with critical leg ischemia, we recently showed that bone marrow mononuclear cell therapy induced the formation of new vessels containing endothelial cells with a ECFC phenotype [6]. Moreover, Yoder et al. [7] have shown that transplanted ECFC acquire a complete endothelial phenotype, maintain a high proliferative potential, and participate in endothelial healing and angiogenesis. In this study, we showed an increase of foot perfusion in the preclinical model of hindlimb ischemia of ECFC isolated from patients treated with treprostinil. Since human cells are hardly detectable in the muscle vasculature, we cannot exclude a paracrine effect of ECFC isolated from patients receiving treprostinil. Indeed, ECFC have been described to secrete several angiogenic pathways that modulate their ability to increase foot perfusion in this preclinical model [27].

The main result of our study is that prostanoid therapy (contrary to PDE5 inhibitors and ERA therapy) increased the numbers and proliferative capacity of ECFC. ECFC have been shown to possess all the characteristics of true endothelial progenitors, based on the clonal relation between EPC and hematopoietic stem cells in patients with myeloproliferative disorders. Indeed, ECFC lack disease markers expressed by early EPC (CFU-Hill or CFU-EC), supporting the concept that CFU-Hill belong to the hematopoietic lineage. This suggests that, in patients with chronic myeloproliferative disorders, ECFC have an origin distinct from that of the hematopoietic malignant clone [7, 45], and probably have true vasculogenic potential [7]. Here we explored ECFC in prostanoid-treated and untreated patients with $\mathrm{PAH}$, a well-characterized vascular disorder, and found that only ECFC were modified by prostanoid treatment, the only therapy shown to reduce mortality among adults and children with PAH [46-49]. Our results confirm importance of ECFC in PAH. Indeed, Toshner et al. [22] describe in patients with PAH and BMPRII mutations that ECFC had a hyperproliferative phenotype and an impaired capacity to form vascular networks, despite an absence of difference in ECFC numbers.

In the present study, CFU-Hill numbers did not differ between the three groups of patients, and did not change during treatment. Results of early-EPC or CFU-Hill counts in PAH are controversial. Asosingh et al. [8] found significantly increased numbers of early EPC in PAH patients compared with controls. In contrast, Junhui et al. [9] found reduced numbers of early EPC, with functional defects, in idiopathic PAH patients compared with controls, a finding confirmed by Diller et al. [10]. 
One limitation of our study is that we did not study the functional status of ECFC from healthy children. In addition, we did not attempt to confirm our findings with another prostanoid, such as IV prostacyclin, that has also been shown to improve survival in this setting.

The higher counts and enhanced angiogenic properties of ECFC in children treated with treprostinil indicate that these cells could contribute to the compensatory adaptive response to increased pulmonary blood flow and/or pressure. It is thus tempting to speculate that ECFC expanded ex vivo might be beneficial in pediatric $\mathrm{PAH}$, especially given the higher counts and functional capacities of ECFC in children compared with adults. Indeed, despite the lack of data on normal ECFC values in children, we found that the ECFC yield in culture for the two older groups of children (with idiopathic and irreversible PAH) was similar to that found in adults $\left[0.2\right.$ and 0.6 colonies per $5 \times 10^{6}$ MNC, respectively, in irreversible and idiopathic PAH, vs 2.0 in reversible PAH and 0.3 in healthy adults (D. Smadja, personal data)]. These results are in line with those of Yoder's group, who observed a hierarchy of proliferative potential between cord blood and adult blood. This result can reasonably be extrapolated to children less than 5 years old, as was the case of our patients with reversible $\mathrm{PAH}$ (median age 2 years).

In conclusion, this study suggests that prostanoids enhance the number and proliferative capacities of ECFC in children with pulmonary hypertension, an effect that may contribute to endothelial repair and/or new vessel formation and, thus, to the observed clinical benefits. The potential interest of ECFC count as a surrogate marker of prostanoid treatment efficacy is currently being investigated.

Acknowledgments We thank Isabelle Zezepanski, Blandine Dizier, Sébastien Bertil, Florence Desvard, Yolande Daigneau, Florence Dao, Yann Burnel and Evelyne Galtier for their excellent technical assistance. This work was supported by research grants from the Leducq TransAtlantic Network of Excellence on Atherothrombosis Research (Grant 04CVD01), Leg Poix (Paris, France) and ARCFA (association pour la recherche en cardiologie du foetus à l'adulte).

Conflict of interest None.

Open Access This article is distributed under the terms of the Creative Commons Attribution Noncommercial License which permits any noncommercial use, distribution, and reproduction in any medium, provided the original author(s) and source are credited.

\section{References}

1. Simonneau G, Robbins IM, Beghetti M, Channick RN, Delcroix M, Denton CP, Elliott CG, Gaine SP, Gladwin MT, Jing ZC, Krowka MJ, Langleben D, Nakanishi N, Souza R (2009) Updated clinical classification of pulmonary hypertension. J Am Coll Cardiol 54:S43-S54

2. Izikki M, Guignabert C, Fadel E, Humbert M, Tu L, Zadigue $P$, Dartevelle P, Simonneau G, Adnot S, Maitre B, Raffestin B, Eddahibi S (2009) Endothelial-derived FGF2 contributes to the progression of pulmonary hypertension in humans and rodents. J Clin Invest 119:512-523

3. Humbert M, Montani D, Perros F, Dorfmuller P, Adnot S, Eddahibi S (2008) Endothelial cell dysfunction and cross talk between endothelium and smooth muscle cells in pulmonary arterial hypertension. Vascul Pharmacol 49:113-118

4. Levy M, Maurey C, Celermajer DS, Vouhe PR, Danel C, Bonnet D, Israel-Biet D (2007) Impaired apoptosis of pulmonary endothelial cells is associated with intimal proliferation and irreversibility of pulmonary hypertension in congenital heart disease. J Am Coll Cardiol 49:803-810

5. Sieveking DP, Buckle A, Celermajer DS, Ng MK (2008) Strikingly different angiogenic properties of endothelial progenitor cell subpopulations: insights from a novel human angiogenesis assay. J Am Coll Cardiol 51:660-668

6. Smadja DM, Bieche I, Silvestre JS, Germain S, Cornet A, Laurendeau I, Duong-Van-Huyen JP, Emmerich J, Vidaud M, Aiach M, Gaussem P (2008) Bone morphogenetic proteins 2 and 4 are selectively expressed by late outgrowth endothelial progenitor cells and promote neoangiogenesis. Arterioscler Thromb Vasc Biol 28:2137-2143

7. Yoder MC, Mead LE, Prater D, Krier TR, Mroueh KN, Li F, Krasich R, Temm CJ, Prchal JT, Ingram DA (2007) Redefining endothelial progenitor cells via clonal analysis and hematopoietic stem/progenitor cell principals. Blood 109:1801-1809

8. Asosingh K, Aldred MA, Vasanji A, Drazba J, Sharp J, Farver C, Comhair SA, Xu W, Licina L, Huang L, Anand-Apte B, Yoder MC, Tuder RM, Erzurum SC (2008) Circulating angiogenic precursors in idiopathic pulmonary arterial hypertension. Am J Pathol 172:615-627

9. Junhui Z, Xingxiang W, Guosheng F, Yunpeng S, Furong Z, Junzhu C (2008) Reduced number and activity of circulating endothelial progenitor cells in patients with idiopathic pulmonary arterial hypertension. Respir Med 102:1073-1079

10. Diller GP, van Eijl S, Okonko DO, Howard LS, Ali O, Thum T, Wort SJ, Bedard E, Gibbs JS, Bauersachs J, Hobbs AJ, Wilkins MR, Gatzoulis MA, Wharton J (2008) Circulating endothelial progenitor cells in patients with Eisenmenger syndrome and idiopathic pulmonary arterial hypertension. Circulation 117: 3020-3030

11. Smadja DM, Mauge L, Sanchez O, Silvestre JS, Guerin C, Godier A, Henno P, Gaussem P, Israel-Biet D (2010) Distinct patterns of circulating endothelial cells in pulmonary hypertension. Eur Respir J (in press)

12. Hur J, Yoon CH, Kim HS, Choi JH, Kang HJ, Hwang KK, Oh BH, Lee MM, Park YB (2004) Characterization of two types of endothelial progenitor cells and their different contributions to neovasculogenesis. Arterioscler Thromb Vasc Biol 24:288-293

13. Hill JM, Zalos G, Halcox JP, Schenke WH, Waclawiw MA, Quyyumi AA, Finkel T (2003) Circulating endothelial progenitor cells, vascular function, and cardiovascular risk. N Engl J Med 348:593-600

14. Ingram DA, Mead LE, Tanaka H, Meade V, Fenoglio A, Mortell K, Pollok K, Ferkowicz MJ, Gilley D, Yoder MC (2004) Identification of a novel hierarchy of endothelial progenitor cells using human peripheral and umbilical cord blood. Blood 104:2752-2760

15. Nagaya N, Kangawa K, Kanda M, Uematsu M, Horio T, Fukuyama N, Hino J, Harada-Shiba M, Okumura H, Tabata Y, Mochizuki N, Chiba Y, Nishioka K, Miyatake K, Asahara T, Hara H, Mori H (2003) Hybrid cell-gene therapy for pulmonary 
hypertension based on phagocytosing action of endothelial progenitor cells. Circulation 108:889-895

16. Zhao YD, Courtman DW, Deng Y, Kugathasan L, Zhang Q, Stewart DJ (2005) Rescue of monocrotaline-induced pulmonary arterial hypertension using bone marrow-derived endothelial-like progenitor cells: efficacy of combined cell and eNOS gene therapy in established disease. Circ Res 96:442-450

17. Wang XX, Zhang FR, Shang YP, Zhu JH, Xie XD, Tao QM, Chen JZ (2007) Transplantation of autologous endothelial progenitor cells may be beneficial in patients with idiopathic pulmonary arterial hypertension: a pilot randomized controlled trial. J Am Coll Cardiol 49:1566-1571

18. Zhu JH, Wang XX, Zhang FR, Shang YP, Tao QM, Zhu JH, Chen JZ (2008) Safety and efficacy of autologous endothelial progenitor cells transplantation in children with idiopathic pulmonary arterial hypertension: open-label pilot study. Pediatr Transplant 12:650-655

19. Galie N, Hoeper MM, Humbert M, Torbicki A, Vachiery JL, Barbera JA, Beghetti M, Corris P, Gaine S, Gibbs JS, GomezSanchez MA, Jondeau G, Klepetko W, Opitz C, Peacock A, Rubin L, Zellweger M, Simonneau G (2009) Guidelines for the diagnosis and treatment of pulmonary hypertension. Eur Respir $\mathbf{J}$ 34:1219-1263

20. Galie N, Hoeper MM, Humbert M, Torbicki A, Vachiery JL, Barbera JA, Beghetti M, Corris P, Gaine S, Gibbs JS, GomezSanchez MA, Jondeau G, Klepetko W, Opitz C, Peacock A, Rubin L, Zellweger M, Simonneau G, Vahanian A, Auricchio A, Bax J, Ceconi C, Dean V, Filippatos G, Funck-Brentano C, Hobbs R, Kearney P, McDonagh T, McGregor K, Popescu BA, Reiner Z, Sechtem U, Sirnes PA, Tendera M, Vardas P, Widimsky P, Sechtem U, Al Attar N, Andreotti F, Aschermann M, Asteggiano R, Benza R, Berger R, Bonnet D, Delcroix M, Howard L, Kitsiou AN, Lang I, Maggioni A, Nielsen-Kudsk JE, Park M, PerroneFilardi P, Price S, Domenech MT, Vonk-Noordegraaf A, Zamorano JL (2009) Guidelines for the diagnosis and treatment of pulmonary hypertension: the task force for the diagnosis and treatment of pulmonary hypertension of the European Society of Cardiology (ESC) and the European Respiratory Society (ERS), endorsed by the International Society of Heart and Lung Transplantation (ISHLT). Eur Heart J 30:2493-2537

21. Dewachter L, Adnot S, Guignabert C, Tu L, Marcos E, Fadel E, Humbert M, Dartevelle P, Simonneau G, Naeije R, Eddahibi S (2009) Bone morphogenetic protein signalling in heritable versus idiopathic pulmonary hypertension. Eur Respir J 34:1100-1110

22. Toshner M, Voswinckel R, Southwood M, Al-Lamki R, Howard LS, Marchesan D, Yang J, Suntharalingam J, Soon E, Exley A, Stewart S, Hecker M, Zhu Z, Gehling U, Seeger W, Pepke-Zaba J, Morrell NW (2009) Evidence of dysfunction of endothelial progenitors in pulmonary arterial hypertension. Am J Respir Crit Care Med 180:780-787

23. Teichert-Kuliszewska K, Kutryk MJ, Kuliszewski MA, Karoubi G, Courtman DW, Zucco L, Granton J, Stewart DJ (2006) Bone morphogenetic protein receptor-2 signaling promotes pulmonary arterial endothelial cell survival: implications for loss-of-function mutations in the pathogenesis of pulmonary hypertension. Circ Res 98:209-217

24. Smadja DM, Bieche I, Susen S, Mauge L, Laurendeau I, d'Audigier C, Grelac F, Emmerich J, Aiach M, Gaussem P (2009) Interleukin 8 is differently expressed and modulated by PAR-1 activation in early and late endothelial progenitor cells. J Cell Mol Med 13:2534-2546

25. Smadja DM, Bieche I, Helley D, Laurendeau I, Simonin G, Muller L, Aiach M, Gaussem P (2007) Increased VEGFR2 expression during human late endothelial progenitor cells expansion enhances in vitro angiogenesis with up-regulation of integrin alpha(6). J Cell Mol Med 11:1149-1161
26. Smadja DM, Bieche I, Uzan G, Bompais H, Muller L, BoissonVidal C, Vidaud M, Aiach M, Gaussem P (2005) PAR-1 activation on human late endothelial progenitor cells enhances angiogenesis in vitro with upregulation of the SDF-1/CXCR4 system. Arterioscler Thromb Vasc Biol 25:2321-2327

27. Smadja DM, d'Audigier C, Weiswald LB, Badoual C, DanglesMarie V, Mauge L, Evrard S, Laurendeau I, Lallemand F, Germain S, Grelac F, Dizier B, Vidaud M, Bieche I, Gaussem P (2010) The Wnt antagonist Dickkopf-1 increases endothelial progenitor cell angiogenic potential. Arterioscler Thromb Vasc Biol (in press)

28. Foubert P, Silvestre JS, Souttou B, Barateau V, Martin C, Ebrahimian TG, Lere-Dean C, Contreres JO, Sulpice E, Levy BI, Plouet J, Tobelem G, Le Ricousse-Roussanne S (2007) PSGL-1mediated activation of EphB4 increases the proangiogenic potential of endothelial progenitor cells. J Clin Invest 117:1527-1537

29. Smadja DM, Gaussem P, Mauge L, Israel-Biet D, Dignat-George F, Peyrard S, Agnoletti G, Vouhe PR, Bonnet D, Levy M (2009) Circulating endothelial cells: a new candidate biomarker of irreversible pulmonary hypertension secondary to congenital heart disease. Circulation 119:374-381

30. Hassoun PM, Mouthon L, Barbera JA, Eddahibi S, Flores SC, Grimminger F, Jones PL, Maitland ML, Michelakis ED, Morrell NW, Newman JH, Rabinovitch M, Schermuly R, Stenmark KR, Voelkel NF, Yuan JX, Humbert M (2009) Inflammation, growth factors, and pulmonary vascular remodeling. J Am Coll Cardiol 54:S10-S19

31. Lam CF, Peterson TE, Croatt AJ, Nath KA, Katusic ZS (2005) Functional adaptation and remodeling of pulmonary artery in flow-induced pulmonary hypertension. Am J Physiol Heart Circ Physiol 289:H2334-H2341

32. Black SM, Fineman JR, Steinhorn RH, Bristow J, Soifer SJ (1998) Increased endothelial NOS in lambs with increased pulmonary blood flow and pulmonary hypertension. Am J Physiol 275:H1643-H1651

33. Celermajer DS, Cullen S, Deanfield JE (1993) Impairment of endothelium-dependent pulmonary artery relaxation in children with congenital heart disease and abnormal pulmonary hemodynamics. Circulation 87:440-446

34. Fadini GP, Avogaro A, Ferraccioli G, Agostini C (2010) Endothelial progenitors in pulmonary hypertension: new pathophysiology and therapeutic implications. Eur Respir J 35:418-425

35. Dussault S, Maingrette F, Menard C, Michaud SE, Haddad P, Groleau J, Turgeon J, Perez G, Rivard A (2009) Sildenafil increases endothelial progenitor cell function and improves ischemia-induced neovascularization in hypercholesterolemic apolipoprotein E-deficient mice. Hypertension 54:1043-1049

36. Iglarz M, Silvestre JS, Duriez M, Henrion D, Levy BI (2001) Chronic blockade of endothelin receptors improves ischemiainduced angiogenesis in rat hindlimbs through activation of vascular endothelial growth factor-no pathway. Arterioscler Thromb Vasc Biol 21:1598-1603

37. Sun CK, Lee FY, Sheu JJ, Yuen CM, Chua S, Chung SY, Chai HT, Chen YT, Kao YH, Chang LT, Yip HK (2009) Early combined treatment with cilostazol and bone marrow-derived endothelial progenitor cells markedly attenuates pulmonary arterial hypertension in rats. J Pharmacol Exp Ther 330:718-726

38. Di Stefano R, Barsotti MC, Melillo E, Iorio M, Santoni T, Armani C, Dell'omodarme M, Ristori C, De Caterina R, Balbarini A (2008) The prostacyclin analogue iloprost increases circulating endothelial progenitor cells in patients with critical limb ischemia. Thromb Haemost 100:871-877

39. Galie N, Ghofrani HA, Torbicki A, Barst RJ, Rubin LJ, Badesch D, Fleming T, Parpia T, Burgess G, Branzi A, Grimminger F, Kurzyna M, Simonneau G (2005) Sildenafil citrate therapy for pulmonary arterial hypertension. N Engl J Med 353:2148-2157 
40. Galie N, Brundage BH, Ghofrani HA, Oudiz RJ, Simonneau G, Safdar Z, Shapiro S, White RJ, Chan M, Beardsworth A, Frumkin L, Barst RJ (2009) Tadalafil therapy for pulmonary arterial hypertension. Circulation 119:2894-2903

41. Simonneau G, Rubin LJ, Galie N, Barst RJ, Fleming TR, Frost AE, Engel PJ, Kramer MR, Burgess G, Collings L, Cossons N, Sitbon O, Badesch DB (2008) Addition of sildenafil to long-term intravenous epoprostenol therapy in patients with pulmonary arterial hypertension: a randomized trial. Ann Intern Med 149:521-530

42. Galie N, Olschewski H, Oudiz RJ, Torres F, Frost A, Ghofrani HA, Badesch DB, McGoon MD, McLaughlin VV, Roecker EB, Gerber MJ, Dufton C, Wiens BL, Rubin LJ (2008) Ambrisentan for the treatment of pulmonary arterial hypertension: results of the ambrisentan in pulmonary arterial hypertension, randomized, double-blind, placebo-controlled, multicenter, efficacy (ARIES) study 1 and 2. Circulation 117:3010-3019

43. Channick RN, Simonneau G, Sitbon O, Robbins IM, Frost A, Tapson VF, Badesch DB, Roux S, Rainisio M, Bodin F, Rubin LJ (2001) Effects of the dual endothelin-receptor antagonist bosentan in patients with pulmonary hypertension: a randomised placebo-controlled study. Lancet 358:1119-1123

44. Humbert M, Barst RJ, Robbins IM, Channick RN, Galie N, Boonstra A, Rubin LJ, Horn EM, Manes A, Simonneau G (2004) Combination of bosentan with epoprostenol in pulmonary arterial hypertension: BREATHE-2. Eur Respir J 24:353-359

45. Piaggio G, Rosti V, Corselli M, Bertolotti F, Bergamaschi G, Pozzi S, Imperiale D, Chiavarina B, Bonetti E, Novara F, Sessarego M, Villani L, Garuti A, Massa M, Ghio R, Campanelli R,
Bacigalupo A, Pecci A, Viarengo G, Zuffardi O, Frassoni F, Barosi G (2009) Endothelial colony forming cells (ECFCs) from patients with chronic myeloproliferative disorders lack the disease-specific molecular clonality marker. Blood 14:3127-3130

46. Barst RJ, Rubin LJ, Long WA, McGoon MD, Rich S, Badesch DB, Groves BM, Tapson VF, Bourge RC, Brundage BH et al (1996) A comparison of continuous intravenous epoprostenol (prostacyclin) with conventional therapy for primary pulmonary hypertension. The primary pulmonary hypertension study group. N Engl J Med 334:296-302

47. Galie N, Humbert M, Vachiery JL, Vizza CD, Kneussl M, Manes A, Sitbon O, Torbicki A, Delcroix M, Naeije R, Hoeper M, Chaouat A, Morand S, Besse B, Simonneau G (2002) Effects of beraprost sodium, an oral prostacyclin analogue, in patients with pulmonary arterial hypertension: a randomized, double-blind, placebo-controlled trial. J Am Coll Cardiol 39:1496-1502

48. Simonneau G, Barst RJ, Galie N, Naeije R, Rich S, Bourge RC, Keogh A, Oudiz R, Frost A, Blackburn SD, Crow JW, Rubin LJ (2002) Continuous subcutaneous infusion of treprostinil, a prostacyclin analogue, in patients with pulmonary arterial hypertension: a double-blind, randomized, placebo-controlled trial. Am J Respir Crit Care Med 165:800-804

49. Olschewski H, Simonneau G, Galie N, Higenbottam T, Naeije R, Rubin LJ, Nikkho S, Speich R, Hoeper MM, Behr J, Winkler J, Sitbon O, Popov W, Ghofrani HA, Manes A, Kiely DG, Ewert R, Meyer A, Corris PA, Delcroix M, Gomez-Sanchez M, Siedentop H, Seeger W (2002) Inhaled iloprost for severe pulmonary hypertension. N Engl J Med 347:322-329 